\title{
DIFFICULTIES EXPERIENCED BY THE MOTHERS OF PEOPLE WITH CYSTIC FIBROSIS ${ }^{1}$
}

\author{
Keila Okuda Tavares², Maria Dalva de Barros Carvalho ${ }^{3}$, Sandra Marisa Pelloso ${ }^{4}$
}

\begin{abstract}
${ }^{1}$ Extract from the dissertation - Cystic fibrosis: multiple perspectives on the being with cystic fibrosis", presented to the Postgraduate Program in Health Sciences, State University of Maringá, in 2009.

2 Physiotherapist. M.Sc in Health Sciences. Professor of the Department of Physiotherapy of the State University of West Paraná. Paraná, Brazil. Email: keilaokudatavares@gmail.com

${ }^{3}$ Ph.D. in Nursing. Professor of the Department of Medicine, the Postgraduate Program in Health Sciences and the Postgraduate Program in Nursing, State University of Maringá (UEM). Paraná, Brazil. Email: mdbcarvalho@uem.br

${ }^{4}$ Ph.D. in Nursing. Professor of the Department of Nursing, the Postgraduate Program in Sciences and the Postgraduate Program in Nursing, UEM. Paraná, Brazil. Email: smpelloso@uem.br
\end{abstract}

\begin{abstract}
This study aimed to understand difficulties experienced by mothers in life with, and caring for, their children with cystic fibrosis. A descriptive-exploratory study with a qualitative character, its population consisted of 14 women. Data collection involved a semi-structured interview. The statements' analysis allowed the identification of two units of meaning: 'The treatment of cystic fibrosis: facing difficulties'; and 'The child's future: the difficult coexistence with the hope for a cure and a normal development'. Difficulties experienced by the mothers relate to disbelief regarding the diagnosis, the mourning for the loss of the dreamt-of child, acceptance of the inevitable and the struggle for the child's life and comfort. It is important for the health team to present another perspective on the health-illness process regarding chronic illnesses in order to support individuals affected and their families in the most efficacious and complete way.
\end{abstract}

KEYWORDS: Cystic fibrosis. Mother-child relations. Family. Nursing.

\section{DIFICULDADES VIVENCIADAS POR MÃES DE PESSOAS COM FIBROSE CÍSTICA}

RESUMO: O objetivo deste estudo é compreender as dificuldades vivenciadas por mães, no convívio e cuidado de seus filhos com fibrose cística. Estudo descritivo-exploratório de caráter qualitativo, cuja população foi composta por 14 mulheres e a coleta de dados realizada por meio de uma entrevista semiestruturada. A análise das falas permitiu identificar duas unidades de significado: o tratamento da fibrose cística: enfrentando dificuldades; e o futuro da criança: a difícil convivência com a esperança de cura e de um desenvolvimento normal. As dificuldades vivenciadas pelas mães estão relacionadas à incredulidade do diagnóstico, o luto pela perda do filho sonhado, a aceitação do inevitável e a luta pela vida e conforto de seu filho. É importante que a equipe de saúde apresente outro olhar sobre o processo saúde-doença crônica para apoiar os indivíduos acometidos e suas famílias de forma mais eficaz e completa.

PALAVRAS CHAVE: Fibrose cística. Relações mãe-filho. Família. Enfermagem.

\section{DIFICULTADES VIVENCIADAS POR LA MADRE DE PERSONAS CON FIBROSIS QUÍSTICA}

RESUMEN: Este estudio tuvo como objetivo comprender las dificultades vivenciadas por las madres en la convivencia y en el cuidado de sus hijos con fibrosis quística. Es caracterizado como cualitativo, descriptivo e exploratorio. La población de estudio fue compuesta por 14 mujeres, la recolección de datos se realizó por medio de una entrevista semi-estructurada. El análisis de las entrevistas posibilitó identificar dos unidades de significado: el tratamiento de la fibrosis quística: enfrentando dificultades; el futuro del hijo: la difícil convivencia con la esperanza de cura y un desarrollo normal. Las dificultades vivenciadas por las madres están relacionadas a la incredulidad del diagnóstico, al luto por la pérdida del hijo imaginario, a la aceptación de lo inevitable y la lucha por la vida y conforto del hijo. Es importante que el equipo de salud presente una nueva manera de mirar el proceso de salud/enfermedad crónica para que sea posible apoyar de forma más eficaz y completa las personas acometidas y sus familias.

PALABRAS CLAVE: Fibrosis quística. Relaciones madre-hijo. Familia. Enfermería. 


\section{INTRODUCTION}

Cystic fibrosis is a systemic metabolic disorder with a genetic origin which is more prevalent among Caucasians and less so among people of African or Asian descent. ${ }^{1}$ In Brazil, because of racial miscegenation, the prevalence data are not linear as in other countries. ${ }^{2}$ Thus, in Brazil, the incidence of cystic fibrosis can vary significantly, although it is estimated that it is approximately $1 / 2,500$ in the southern region, similar to that of Europe, and 1/10,000 in the rest of the country. ${ }^{3}$

Cystic fibrosis is characterized by situations of obstructive tubulopathies in organs such as the lungs and pancreas, ${ }^{4}$ and chronic lung disease, which is considered to be mainly responsible for the morbidity and mortality. ${ }^{5}$ The diagnosis may be made in association with the clinical picture and the evaluation of the concentration of chloride in the sweat ${ }^{6}$ or through Neonatal Screening using the immuno-reactive trypsinogen test. ${ }^{7}$ The diagnosis of cystic fibrosis significantly affects the routine of the entire family, principally that of the mother-child binomial, as the ill person is usually obliged to live in a routine of hospitalization, painful treatment, and sequelae which impose limitations and require long periods of supervision and care ${ }^{8}$ interruption of routine activities, financial hardship, pain and living with the real possibility of death. ${ }^{9}$

Various studies have been undertaken in Paraná addressing cystic fibrosis, either in isolation or in the context of Neonatal Screening. The majority of these address epidemiological ${ }^{10-11}$ or nutritional ${ }^{12}$ aspects, associated health problems, ${ }^{13}$ diagnostic tests ${ }^{14}$ and evaluation of the Neonatal Screening Program. ${ }^{15}$ Only two studies were identified addressing the importance of the organization of support for those with cystic fibrosis and the intersubjectivity in the context of the family. ${ }^{16-17}$

There are few Brazilian studies analyzing the social and family issues involved in the routine of those with cystic fibrosis. This is an important aspect to be investigated, as the centers of excellence in Brazil, and the health professionals involved in the treatment of people who present this disease, need to know the difficulties faced by the mothers of these patients, in order to better manage the attendance and the care.

As a result, the present study is justified. It aims to understand the difficulties experienced by mothers in living with and caring for their children with cystic fibrosis.

\section{METHODS}

This is a descriptive-exploratory study with a qualitative character. The study population was made up of mothers of individuals with cystic fibrosis, attended and monitored in the Cystic Fibrosis Outpatient Center of the University Hospital of the West of Paraná (HUOP), in the period March - April 2009. This outpatient center attends those with cystic fibrosis from the Western Region of Paraná. The mothers were contacted, via telephone, and invited to participate in the research. Following its arrangement, the interview was held in the subjects' homes in private. Data collection was undertaken using a semi-structured interview based on the guiding question: "for you, what is it to be the mother of an individual with cystic fibrosis?" The interviews were recorded, using a digital recorder, and transcribed in full, for later analysis.

Following transcription, the texts of the interviews were identified with the letter " $\mathrm{M}$ " (mother), followed by numbers, and their analysis was based in guidelines: reading of each transcribed text in full (immersion in the accounts); reading of each text, focussing on the guiding question, aiming to identify "assertions" which presented relevant meanings; description of what was implicit in these assertions, taking into account the guiding question; grouping of the assertions with similar meanings, thus distinguishing the "units of meaning"; and, finally, comprehensive analysis was undertaken of the "units of meaning", in order to investigate the essence of the phenomenon studied. ${ }^{18}$ For discussion of the data, the theoretical framework related to the theme of the study was used.

This study was considered and approved by the Committee for Ethics in Research with Human Beings of the State University of Maringá (UEM) (Decision n. 661/2008) and was undertaken in accordance with the ethical standards required by Resolution N. 196/96 of the National Health Council. All the mothers who agreed to participate read and signed the Terms of Free and Informed Consent.

\section{RESULTS}

On the HUOP Outpatient Center's list of patients, there were the names of 19 individuals with cystic fibrosis. Only one mother, who had two children with the disease, declined to participate. Fourteen mothers were interviewed, as three of them had two children with cystic fibrosis. They were aged between 25 and 50 years old, with a mean age of 37 years old. In relation to how their 
children were diagnosed, in 11 cases $(64.71 \%)$ this was early, through Neonatal Screening, and in six cases $(35.29 \%)$ it was late. Regarding the age of the children who had cystic fibrosis, ten $(58.82 \%)$ were children, aged between six months and nine years old; five $(29.41 \%)$ were adolescents, aged between 12 and 18 years old; and two $(11.76 \%)$ were adults, one aged 22 years old and the other 28 . Regarding the children who had a late diagnosis, when this was established they had a mean age of 10 years old.

Through exhaustive reading of the transcribed accounts, and their analysis, two units of meaning emerged: "The treatment of cystic fibrosis: facing difficulties" and "The child's future: the difficult coexistence with the hope for a cure and a normal development".

\section{The treatment of cystic fibrosis: facing difficulties}

For a long time, the mothers of the children who were diagnosed late had to live with their children presenting complications related to the illness and to the inappropriate treatment resulting from a mistaken diagnosis. They reported that the health professionals' lack of knowledge for establishing the correct diagnosis resulted in suffering from them, their children, and the family. They remembered the sadness of seeing their children always "sick".

The only thing they said was that it was, it was bronchitis, just bronchitis, oh my God. And every month that same medication (M5).

The mothers who received the diagnosis through Neonatal Screening reported suffering and shock resulting from the news that their child had a serious and incurable illness. Some did not accept the diagnosis, mainly because of the prognosis. Many became emotional reporting this experience, remembering that they felt totally unsupported and lost.

[...] I was very distressed by it, I was very distressed (M6).

God, I was at my wits end. I couldn't accept it at all (M13).

Following diagnostic confirmation, it is necessary to monitor and treat the individuals who have cystic fibrosis. The families are advised to seek the Paraná Mucoviscidosis Assistance Association (AAMP), based in Curitiba, where there are also two specialized treatment centers. ${ }^{19}$

The mothers experienced positive feelings in knowing that specialized care was a reality in the State, but as time went on, and with the routine of journeys to Curitiba, the capital of Paraná, they began to experience the tiredness that this treatment and monitoring require. Some mothers reported that they did not know Curitiba, and that this fact caused them a certain discomfort on their first journeys, and that they travelled at least once a month. When the children presented complications, the number of journeys increased, as, in the towns where they lived, they could not find professionals accustomed to working with the disease. The distance between these families' cities and Curitiba, where the AAMP is located, is between 443 and 636 $\mathrm{km}$. Later, a specialized attention center was opened in the West Paraná region, and the situation became less difficult, as the distance between the patients' cities of origin and the teaching hospital varied between 46 and $145 \mathrm{~km}$. Even so, some mothers report that these "smaller" distances can be difficult to cope with when there are complications.

It was difficult, we had no idea, there was no doctor here, everything was in Curitiba and I didn't know anything, anybody there [...]. It didn't work out with the first doctors we contacted, even when they said they were familiar with cystic fibrosis, they didn't medicate correctly. So it was really difficult. (M2).

The difficulty of not having a doctor nearby. 100 $\mathrm{km}$, when she dehydrated, it felt like an eternity until I arrived (M9).

In some cases, the mothers did not tell of the problem to anybody, not even to relatives outside their core group. In others, they reported that they did not receive the necessary support from their own family. In some situations, it is the individuals affected by cystic fibrosis who choose not to tell other people that they have the disease. One of them reported that when she told somebody else, she stopped spending time with her.

So within my family, also, almost nobody supported me. The person who supported me most was my mother (M13).

Another difficulty faced by the mothers who participated in the study is having to live with the disease's daily treatment. It is a tiring routine of schedules, medications and respiratory physiotherapy, besides the visits to the multidisciplinary team. In addition to this, inpatient treatment due to complications from the disease and for the administration of certain medications is frequent, causing them to withdraw temporarily from their everyday activities.

[...] I just find it hard work. You know, kind of stressful. Mainly when she has to go on antibiotics, I 
think that more inhalation than usual, and physiotherapy, is one of those things, which tires you sometimes. There are days when we are drained (M2).

[...] When she was six months old she caught a bacteria, and she had to spend twenty-one days in hospital. So, for me, that was an impact. Twenty-one days, you think, like, 'My God'. Normally we spend two days in hospital when it is something more simple. And you think that is enough, so twenty-one days... [...] (M10).

\section{The child's future: the difficult coexistence with the hope for a cure and a normal development}

The mothers reported that it is necessary to accept that the child has cystic fibrosis, to face the disease and to be realistic; they admit that living with cystic fibrosis is not easy and that because of this they have to be determined and persist in this daily struggle for their child's well-being. Although the routine of treatment for cystic fibrosis is stressful, they do not give up on complying with all the health team's recommendations; they know what they must do to keep their children away from complications and the risk of death and know that if everybody does their part, good results will be achieved.

[...] doing the correct treatment, seeking support, everything. Then it becomes easier. Turning your back on it would make things more difficult. Pretending that it does not exist is worse (M1).

The mothers' experience with the chronic disease gave rise to a situation of suffering and worry. At such times, it is common to take strength from religion. It was possible to understand that they believe that a greater force can protect their children from the complications of the cystic fibrosis, and that, even, a cure may occur. Their faith allows them to believe that this possibility exists, and they hope that their children may totally recover their "health", that they may "get better".

Because the doctors explained to us that there is no cure, but for God nothing is impossible [...] (M12).

Besides a cure, the mothers hope that their children will present the growth and development appropriate for each phase of life. They hope that they will pass through the phase of childhood, adolescence and arrive at the adult phase, like any other person. They would like them to study and have a profession, a family, a life like any other individual. They have dreams and expectations which any other mother has in relation to her children.
[...] a normal life, to study, for her to have a job. Of course, she will have to be careful in certain ways [...] (M2).

[...] I dream about him, studying, going to university and being a normal child (M6).

\section{DISCUSSION}

The mothers of those who were diagnosed late spent a long time passing from one hospital to another and from one doctor to the next, with their children undergoing multiple tests, and experiencing total uncertainty regarding the diagnosis of their children. This situation was so stressful that they actually felt relieved on receiving the diagnosis, even though it was of a chronic illness. They exchanged ambiguity for certainty, which allowed a little hope and security with the correct treatment, and with that, a reduction in their children's suffering. However, this could have been avoided if they had received appropriate assistance, easy access to the health services and, mainly, appropriate communication and valuing of the information regarding the child's symptoms. ${ }^{20}$

The mothers who received an early diagnosis, on the other hand, passed through a phase of mourning for the loss of the child they had imagined. The development of this loss was permeated by conflicts. A unique and untransferable experience was revealed, marked by tears, desperation and anxiety. ${ }^{21}$ In this situation, they may feel incomplete and incapable, and show ideas indicating depression. The mourning, even though painful, is necessary in order to accept the real child; based on this elaboration, the process of reversion and acceptance of reality begins. The loss provokes an avalanche of emotions which change the person's psychological life, and the duration of this process depends on the intensity of the relationship of the person with the object which was lost. Recognizing this dynamic in the process of accepting the loss of the imagined child is fundamental for the involvement of the mothers in the act of caring for the child with cystic fibrosis. ${ }^{22}$

Receiving the news of the diagnosis, whether early or late, is a complicated event, marked by sadness, distress and doubts. The mothers feel themselves to be weakened even further when the health team limits itself only to transmitting the diagnosis. It is necessary for the team to be available to respond to the questions and provide the mothers with guidance regarding the disease and its treatment, which can reduce these feelings' impact and contribute to the acceptance. ${ }^{23}$ 
The mothers' biggest allies in this journey of caring for children with cystic fibrosis are the specialized centers and the associations which support the patients and their families. In Brazil, there are 33 centers specialized in treating the disease, and 25 associations linked to the Brazilian Association for Mucoviscidosis Assistance (ABRAM). These distribute the high cost medications used in the treatment of cystic fibrosis. In these locales, the families find support and guidance, as well as other families in similar situations, for sharing experiences and information. ${ }^{19}$

The treatment centers and the associations also have another important role, that of publicizing the disease. Many individuals receive a late diagnosis, and are treated inappropriately for a large part of their lives, developing important physical and emotional changes. In Brazil, the implantation of the Neonatal Screening Program for cystic fibrosis is recent, and there may still be many individuals remaining undiagnosed. The more people know about the disease and its manifestations, whether health professionals or not, the more cases shall be recognized. This publicity is extremely necessary, as the mothers reported the lack of knowledge and the population's prejudice in relation to cystic fibrosis, which limits their support network.

Cystic fibrosis, in spite of not causing visible physical changes, is an unknown disease for the majority of the population. Many people do not seek information about the disease when they meet a person who has it, as it is easier to avoid the situation of entering into contact with something "different". Because of this, informing the community in general about cystic fibrosis can avert this type of behavior and the families' isolation.

One of the mothers in this study lost her husband some months prior to being interviewed. She was living with her sister's family, as she had been encouraged to move from her city so as to be closer to her relatives, who made themselves available to assist in the care of her children. Mothers of children with this chronic disease feel a need for this type of attitude..$^{21}$ They consider their family, principally their husband and their own parents, to be their main source of support. ${ }^{24}$ The strengthening of the social support network of mothers of persons with cystic fibrosis passes through a stage of embracement on the part of the partner and relatives from outside the family core group.

The social network of extrafamilial relationships functions as a long-term coping strategy. People who are close tend to help the others to overcome adversity. ${ }^{25}$ Parents of people with cystic fibrosis report the importance of receiving support from social groups such as friends, parents of children in similar situations, the health team and the associations. In these institutions it is possible to share information and experiences, and also to receive encouragement to carry on. ${ }^{16,26-27}$

All of the mothers interviewed reported as important the presence of a health professional and the outpatient center specialized in treating cystic fibrosis in the West Paraná Region teaching hospital; not just because of the fact of their being familiar with the disease and having made possible the creation of a multidisciplinary care center in the region, but also because of the fact that it is always available to provide guidance and embrace these people. A health team with a different vision of the health-illness process in the context of chronic illnesses can support the individuals affected and their families in a more efficacious and complete way, through an approach which is not directed at technical support alone, but towards social practice.

This situation is not common in the State, as not all the regions have a specialized cystic fibrosis outpatient center. The majority $(79 \%)$ of municipalities in the state of Paraná are small, with 20,000 inhabitants, and those who live there are not accustomed to big cities such as Curitiba and find it difficult to travel around in such places, and this, without doubt, is a further problem to be faced.

One of the biggest difficulties faced by the mothers of individuals with cystic fibrosis is the frequent hospitalization of their children. The parents may experience feelings of lack of control and even lack of liberty in relation to their lives, because of the routine of hospital environment rules and procedures. The mothers put themselves in their children's place, coming to feel that they too are hospitalized. The child's state of health creates constant tension, because of the uncertainty regarding outcome, the need to take responsibility for care, and not receiving the appropriate advice from the health team. This causes them to live in a constant state of alert. ${ }^{28}$

There are also cases in which difficulties in relating between the professionals and the mothers compromise the sharing of information. During inpatient treatment, interaction with the health professionals is important, so as to perceive how this time is being perceived and how individuals involved are being affected, so as to assist these people in the most complete way. ${ }^{28}$ When a relationship of trust and respect is established, it is 
possible to transform the hospital environment into a less distressing place. $^{29}$

Mothers who have children with a chronic illness often leave the job market so as to dedicate themselves totally to their children. This may be related to the type of sequelae which the disease entails, as in the case of diseases which present physical and mental changes. ${ }^{24}$ In this study, only one mother stopped working so as to care for her child. Those who were already working continued working, as, even receiving the high-cost medications for the treatment from the government free of charge, they needed a higher income to meet other needs arising from the disease. There is no doubt that this triple work day (profession, housewife and caregiver) contributes to the intensifying the difficulties which they face.

On the other hand, the mothers' discourses revealed that after the initial impact of the diagnosis, through acceptance and the desire to beat cystic fibrosis, it was possible to attribute new meaning to life and to the disease. The strategy was to know the disease in order to take control of the situation, driving away the feelings of fear and impotence. With time, they adapted and began to see the problem with different eyes, adopting positive attitudes towards the situation.

One important limit of this study was the research subjects, who, due to living in the West Region of Paraná, have different attendance in the outpatient center of a city which is far smaller than the state capital, Curitiba. They do not face the difficulties inherent to a metropolis. Nevertheless, this limit made it possible to show the need for new public policies increasing both the numbers of centers of excellence and their presence in parts of the country outside the major cities, so as to humanize the attendance, reducing the mothers' difficulties in facing a chronic disease.

\section{FINAL CONSIDERATIONS}

The accounts revealed that it is important for the health team to present another perspective on the health-illness process in the context of chronic diseases so that it may support the individuals affected by cystic fibrosis and their families more efficaciously and completely - in the case of this study, the mothers. This new prospective is the understanding of the phenomenon of being the mother and caregiver for a person with cystic fibrosis. In this way, it is necessary to have sensitivity to perceive that these families are facing an unplanned-for period in their lives, experiencing many difficulties based on the diagnosis, such as suffering and shock at the news of a serious and uncontrollable disease, the small number of places which are specialized in attending it, people's prejudice in relation to a little-known disease, the tiring routine of the treatment and the frequent hospitalizations due to cystic fibrosis and its complications. It is important to understand that this condition is not transient, that it requires of the mother unconditional dedication, total attention to the child's health conditions and a permanent and close coexistence with death.

Understanding how the process of adaptation occurs in each case allows different educational and relational approaches to be developed, with the aim of helping these people in their journey with cystic fibrosis. One important aspect which deserves to be emphasized is the existence of an outpatient center for cystic fibrosis care in the West of Paraná, which facilitated the mothers' exhausting routine. This is a point which deserves reflection, indicating the need to spread centers of excellence for better care and monitoring to parts of the country outside the major cities. In addition to facilitating the mobility of the mother and her child, it allows a closer coexistence which facilitates the control of the disease. A de-centralized center of excellence prepares the various professionals better to provide quality attendance, both in the technical and humane aspects, undertaking their role more effectively within the support networks for these individuals and their family members.

\section{REFERENCES}

1. Raskin S, Pereira-Ferrari L, Reis FC, Rosario NA, Ludwig N, Valentim L, et al. High allelic heterogeneity between Afro-Brazilians and EuroBrazilians impacts cystic fibrosis genetic testing. Genet Test. 2003; 7(3):213-8.

2. Raskin S, Pereira-Ferrari L, Reis FC, Abreu F, Marostica P, Rozov $\mathrm{T}$, et al. Incidence of cystic fibrosis in five different states of Brazil as determined by screening of p.F508del, mutation at the CFTR gene. J Cyst Fibros. 2008 Jan; 7(1):15-22.

3. Alvarez AE, Ribeiro AF, Hessel G, Bertuzzo CS, Ribeiro JD. Fibrose cística em um centro de referência no Brasil: características clínicas e laboratoriais de 104 pacientes e sua associação com o genótipo e a gravidade da doença. J Pediatr. 2004 Set-Out; 80(5):371-9.

4. Rosa FR, Dias FG, Nobre LN, Morais HA. Fibrose cística: uma abordagem clínica e nutricional. Rev Nutr. 2008 Nov-Dez; 21(6):725-37. 
5. Muramatu LH, Stirbulov R, Forte WCN. Características funcionais pulmonares e uso de broncodilatador em pacientes com fibrose cística. J Bras Pneumol. 2013 Jan-Fev; 39(1):48-55.

6. Boeck K, Wilschanski M, Castellani C, Taylor C, Cuppens H, Dodge J, et al. Cystic fibrosis: terminology and diagnostic algorithms. Thorax. 2006 Nov; 61(7):627-35.

7. Rodrigues R, Gabetta CS, Pedro KP, Valdetaro F, Fernandes MIM, Magalhães PKR, et al. Cystic fibrosis and neonatal screening. Cad Saúde Pública. 2008 Jul; 24(Suppl.4):475-84.

8. Souza SS, Bonetti A, Meirelles BHS, Mattosinho MMS, Coelho MS, Argenta C. Living with a chronic disease in a fishing community. Acta Paul Enferm. 2010 Mar-Apr; 23(2):194-9.

9. Cabizuca M, Mendlowicz M, Marques-Portella C, Ragoni C, Coutinho ESF, Souza W, et al. Os pacientes invisíveis: transtorno de estresse pós-traumático em pais de pacientes com fibrose cística. Rev Psiquiatr Clin. 2010 Jan; 37(1):6-11.

10. Luz GS, Carvalho MBD, Pelloso SM, Higarashi IH. Prevalência das doenças diagnosticadas pelo programa de triagem neonatal em Maringá, Paraná, Brasil: 2001-2006. Rev Gaúcha Enferm. 2008 Set; 29(3):446-53.

11. Carvalho MDB, Pelloso SM, Higarashi IH, Luz GS. Neonatal Screening Program coverage in Maringá (PR), 2001 to 2006. Acta Paul Enferm. 2008 Jan-Mar; 21(1):89-93.

12. Gaspar MCA, Chiba SM, Gomes CET, Juliano Y, Novo NF, Ancona-Lopez F. Resultado de intervenção nutricional em crianças e adolescentes com fibrose cística. J Pedriatr. 2002 Mar-Abr; 78(2):161-70.

13. Döring G, Conway SP. Osteoporosis in cystic fibrosis. J Pediatr. 2008 Jan-Feb; 84(1):1-3.

14. Júnior OK, Franchini CFM. Teste do suor em pacientes pediátricos para diagnóstico de fibrose cística. Estamos diagnosticando precoce e corretamente a doença? Pediatr Mod. 2004 Set-Out; 40(5):214-5.

15. Santos GPC, Domingos MT, Wittig EO, Riedi C, Rosário N. Programa de triagem neonatal para fibrose cística no Estado do Paraná: avaliação após 30 meses de sua implantação. J Pediatr. 2005 MaiJun; 81(3):240-4.

16. Luz GS, Carvalho MDB, Silva MRS. O significado de uma organização de apoio aos portadores e familiares de fibrose cística na pespectiva das famílias. Texto Contexto Enferm. 2011 Jan-Mar; 20(1):127-34.
17. Luz GS, Lunardi VL, Pimentel EDC, Pelloso SM, Carvalho MDB. A intersubjetividade no contexto da família de pessoas com fibrose cística. Rev Bras Enferm. 2012 Mar-Abr; 65(2):251-6.

18. Giorgi AP. Phenomenology and psychological research. Pittsburgh (US): Duquesne University Press; 2008.

19. Associação de Assistência à Mucoviscidose do Paraná [página da Internet]. Centros de tratamento [acesso 2009 Jul 20]. Disponível em: http://www. aampr.org.br./

20. Luz GS, Santos SSC, Lunardi VL, Pimentel EDC, Pelloso SM, Carvalho MDB. A intersubjetividade no contexto da família de pessoas com fibrose cística. Rev Bras Enferm 2012. Mar-Abr; 65(2):251-6.

21. Barbosa MAM, Chaud MN, Gomes MMF. Experiences of mothers of disabled children: a phenomenological study. Acta Paul Enferm. 2008 Jan-Mar; 21(1):46-52.

22. Boff J, Caregnato RCA. História oral de mulheres com filhos portadores de Síndrome de Down. Texto Contexto Enferm 2008. Jul-Set; 17(3):578-86.

23. Gondim KM, Carvalho ZMF. Sentimentos das mães de crianças com paralisia cerebral à luz da Teoria de Mishel. Esc Anna Nery. 2012 Jan-Mar; 16(1):11-6.

24. Milbrath VM, Cecagno D, Soares DC, Amestoy SC, Siqueira HCH. Being a woman, mother to a child with cerebral palsy. Acta Paul Enferm. 2008 Jul-Sep; 21(3):427-31.

25. Araújo YB, Collet N, Gomes IP, Nóbrega RD. Enfrentamento do adolescente em condição crônica: importância da rede social. Rev Bras Enferm. 2011 Mar-Abr; 64(2):281-6.

26. Furtado MCC, Lima RAG. O cotidiano da família com filhos portadores de fibrose cística: subsídios para a enfermagem pediátrica. Rev Latino-Am Enferm. 2003 Jan-Fev; 11(1): 66-73.

27. Luz GS. Fibrose cística: des-velando o significado para a família [dissertação]. Maringá (PR): Universidade Estadual de Maringá, Programa de Pós-Graduação em Enfermagem; 2008.

28. Costa JB, Mombelli MA, Marcon SS. Avaliação do sofrimento psíquico da mãe acompanhante em alojamento conjunto pediátrico. Estud Psicol. 2009 Jul-Set; 26(3):317-25.

29. Morais GSN, Costa SFG. Experiência existencial de mães de crianças hospitalizadas em Unidade de Terapia Intensiva Pediátrica. Rev Esc Enferm USP. 2009 Set; 43(3):639-46. 